\title{
Morphological description and DNA barcoding study of sand rice (Agriophyllum squarrosum, Chenopodiaceae) collected in Kazakhstan
}

Yuliya Genievskaya', Saule Abugalieva', Aibatsha Zhubanysheva² and Yerlan Turuspekov ${ }^{1 *}$

From 4th International Scientific Conference "Plant Genetics, Genomics, Bioinformatics and Biotechnology" (PlantGen 2017) Almaty, Kazakhstan. 29 May - 2 June 2017

\begin{abstract}
Background: Sand rice (Agriophyllum squarrosum (L.) Moq.) is an annual shrub-like plant adapted to the mobile sand dunes in desert and semi-desert regions of Asia. It has a balanced nutrient composition with relatively high concentration of lipids and proteins, which results in its nutrition being similar to legumes. Sand rice's proteins contain the full range of essential amino acids. However, calories content is more similar to wheat. These features together with desert stress resistance make sand rice a potential food crop resilient to ongoing climate change. It is also an important fodder crop (on young stages of growth) for cattle in arid regions of Kazakhstan. In our work, sand rice samples were collected from two distant regions of Kazakhstan as a part of the nation-wide project to determine genetic variation of the native flora.
\end{abstract}

Results: Samples were collected in western and southeastern parts of Kazakhstan separated by distances of up to $1300 \mathrm{~km}$. Sequences of the nuclear ribosomal DNA ITS1-5.8S-ITS2 region and the chloroplast matK gene confirmed the identity of species defined by morphological traits. Comparison with GenBank sequences revealed polymorphic sequence positions among Kazakh populations and GenBank references, and suggested a distinction among local populations of sand rice. The phylogenetic analysis of nucleotide sequences showed a clear partition of $A$. squarrosum (L.) Moq. from Agriophyllum minus Fisch. \& C.A. Mey, which grows in the same sand dunes environment.

Conclusions: DNA barcoding analyses of ITS and matK sequences showed a segregation of A. squarrosum from A. minus into separate clades in Maximum-Likelhood dendrograms. ITS analysis can be successfully used to characterize A. squarrosum populations growing quite distant from each other. The data obtained in this work provide the basis for further investigations on $A$. squarrosum population structure and may play a role in the screening of sand rice plants growing in desert and semi-desert environments of Central Asia and China.

Keywords: Agriophyllum squarrosum, Agriophyllum minus, Sand rice, Shrub, DNA barcoding, ITS, matK

* Correspondence: yerlant@yahoo.com

${ }^{1}$ Institute of Plant Biology and Biotechnology, Almaty, Kazakhstan050040

Full list of author information is available at the end of the article 


\section{Background}

Deserts and semi-deserts occupy more than the half of Kazakhstan's territory. A very limited number of plants can survive in extreme conditions of xeric, hot sands. One of the examples of successfully growing plants in harsh desert environments is sand rice, Agriophyllum squarrosum (L.) Moq. In Kazakhstan and Central Asia it is known as kumarchik (from the Turkic "kum" - sand). It is an annual endemic plant found in desert and semidesert regions of Asia. A. squarrosum belongs to the tribe Corispermeae within the subfamily Chenopodioideae of Chenopodiaceae [1, 2]. Agriophyllum contains five species and four of them, including A. squarrosum, occur in Kazakhstan [3].

A. squarrosum (old name: A. arenarium M.Bieb.) is a shrub-like plant $20-100 \mathrm{~cm}$ tall. Stems are erect, light green, firm, ribbed, covered with ramified hairs when young, and branched from the base. Leaves are sessile, lanceolate to linear, $1.3-7 \mathrm{~cm} \times 1-10 \mathrm{~mm}$ in size. Small flowers form the inflorescence, a spike. Spikes are axillary, sessile, dense, ovoid or ellipsoid in shape. Seeds are subglobose, 1.3-2 mm long, sometimes speckled with light brown two-pointed cornicles. Sand rice flowers from August to October; seeds ripen during the same period. Seeds of $A$. squarrosum are very light, covered in a membranous husk. After ripening, the husk is cracked into two parts and seeds are easily dispersed by wind [3].

Sand rice has a diverse economic importance. Each organ of this plant, from root to seeds, finds its own application in human's life. Although the plants grow in infertile sand, A. squarrosum has a high concentration of nutrients in its seeds and other organs. Since ancient times, nomads had used seeds of sand rice as a food [4]. As it is not possible to grow cereals in the desert on a large scale, shepherd-nomads collected sand rice seeds, ground them and used the flour for flat cakes and porridge [5]. Nutritional properties of sand rice represent a combination of relatively high proteins $(23.2 \%$ of dry weight) and lipids (9.7\% of dry weight) content together with carbohydrates (up to $45 \%$ of dry weight). Proteins include the full set of essential amino acids required for human diet [6]. The nutritional properties are similar to legumes, such as soybean or chickpea, but with a lower amount of calories. At the vegetative stage Agriophyllum species are heavily used as a pasture fodder plants for sheep and camels [7]. Young fresh stems and leaves of sand rice are suitable for silage. Medical usage of sand rice is also well described in the literature. According to the ancient books in Mongolian medicine, decoction of seeds had been used as antipyretic and analgesic medical [8]. In China, A. squarrosum is routinely used for the treatment of kidney inflammation [6].

The root system of sand rice plants has a rather unique structure and includes a long taproot and almost equally long lateral roots near the soil surface. The length of the taproot can be comparable to the height of above ground organs $[9,10]$. Some lateral roots can reach a length of $5 \mathrm{~m}$ by the time the main stem has grown to just $67 \mathrm{~cm}$ [6]. They enable the plant to gain a foothold in sand and withstand strong sandstorms. Therefore, A. squarrosum has been cultivated in deserts and semi-deserts of Central Asia for sand stabilization $[11,12]$.

Physiology and morphology of sand rice are ideally adapted to the extreme desert conditions [13], which make $A$. squarrosum interesting for studying its genomic basis of xeric adaptations. In the last 10 years, there were several works dedicated to the search of candidate genes responsible for the tolerance to heat and drought stresses [14]. One of the current primary goals is the domestication of sand rice in desert environments [15] via development of plants with larger grains and higher yield, and to exclude unfavorable phenotypic traits such as seed shattering, thorns, etc.

A survey of the scientific literature revealed that, at present, no studies have been published on the taxonomy of the small genus Agriophyllum. We conducted this study to identify the intraspecific genetic diversity of A. squarrosum using barcoding markers and to see how clearly it is diverged from $A$. minus, which also widely grows in desert areas of Kazakhstan, partly in sympatry with $A$. sqarrosum. DNA barcoding is a powerful and efficient tool for the identification of poorly studied species [16-18]. Previous reports suggested that phylogenetic analysis of plants in the Caryophyllales can be effective using major universal DNA markers [19]. In our study here the chloroplast genome marker matK [20] and the nuclear ribosomal DNA region including the internal transcribed spacers 1 and 2 (ITS) together with the 5.8S rRNA gene [21] were utilized. The study is a part of larger nation-wide project [22] for genotyping of endemic, rare, and economically important species of Kazakhstan's flora that combine efforts of local botanists and geneticists from biotechnology research organizations, botanical gardens, state nature parks and reserves.

\section{Methods}

Materials sampling and morphological identification

A total of seven populations of Agriophyllum species were collected from two distant regions of Kazakhstan (Table 1).

The first population of A. squarrosum in western Kazakhstan, Aktobe region, Bol'shie Barsuki Sands was collected in 2015. The remaining four populations in southeastern Kazakhstan, Almaty region, Moyynkum Sands were collected in 2016 (Fig. 1).

Both the western and southeastern territories are characterized by extreme desert climate and are usual habitats for sand rice $[3,23]$. In order to compare morphology and 
Table 1 Materials and sampling locations

\begin{tabular}{|c|c|c|c|c|}
\hline Region & Species, population № & Number of collected plants & Coordinates & Elevation, m \\
\hline \multirow[t]{5}{*}{$\begin{array}{l}\text { Southeastern KZ } \\
\text { (Almaty region, Moyynkum Sands) }\end{array}$} & A. squarrosum pop.1 & 10 plants & $\begin{array}{l}44^{\circ} 34^{\prime} 55.1^{\prime \prime} \mathrm{N} \\
076^{\circ} 58^{\prime} 30.3^{\prime \prime} \mathrm{E}\end{array}$ & 411 \\
\hline & A. squarrosum pop.2 & 5 plants & $\begin{array}{l}44^{\circ} 43^{\prime} 24.1^{\prime \prime} \mathrm{N} \\
076^{\circ} 44^{\prime} 21.3^{\prime \prime} \mathrm{E}\end{array}$ & 409 \\
\hline & A. squarrosum pop. 3 & 10 plants & $\begin{array}{l}44^{\circ} 38^{\prime} 34.2^{\prime \prime} \mathrm{N} \\
076^{\circ} 57^{\prime} 03.5^{\prime \prime} \mathrm{E}\end{array}$ & 434 \\
\hline & A. squarrosum pop.4 & 10 plants & $\begin{array}{l}44^{\circ} 39^{\prime} 48.1^{\prime \prime} \mathrm{N} \\
076^{\circ} 47^{\prime} 25.6^{\prime \prime} \mathrm{E}\end{array}$ & 429 \\
\hline & A. minus pop.1 & 5 plants & $\begin{array}{l}44^{\circ} 13^{\prime} 27.1^{\prime \prime} \mathrm{N} \\
076^{\circ} 58^{\prime} 30.3^{\prime \prime} \mathrm{E}\end{array}$ & 463 \\
\hline \multirow[t]{2}{*}{$\begin{array}{l}\text { Western KZ } \\
\text { (Aktubinsk region, Bol'shie Barsuki Sands) }\end{array}$} & A. squarrosum pop. 5 & 10 plants & $\begin{array}{l}47^{\circ} 51^{\prime} 37^{\prime \prime} N \\
059^{\circ} 52^{\prime} 58^{\prime \prime} \mathrm{E}\end{array}$ & 189 \\
\hline & A. minus pop. 2 & 5 plants & $\begin{array}{l}47^{\circ} 22^{\prime} 62^{\prime \prime} \mathrm{N} \\
059^{\circ} 59^{\prime} 28^{\prime \prime} \mathrm{E}\end{array}$ & 183 \\
\hline
\end{tabular}

genetic diversity among populations of two closely related species, two populations of $A$. minus were also collected in the same regions of Kazakhstan. Total distances between the two sampling areas varied from 1250 to1300 $\mathrm{km}$. The approximate distance between each of the populations from one region is $4-6 \mathrm{~km}$. The populations were separated from each other by sand dunes not inhabited by the species. Whole plants and segments of branches were chosen as materials for our analysis. Entire plants were used to make herbarium voucher specimens. Dry branches and seeds were packed and annotated on individual paper bags in order to avoid contamination.

\section{DNA extraction, amplification and sequencing}

Three plants from each population were chosen for molcular analysis. Total genomic DNA was extracted from

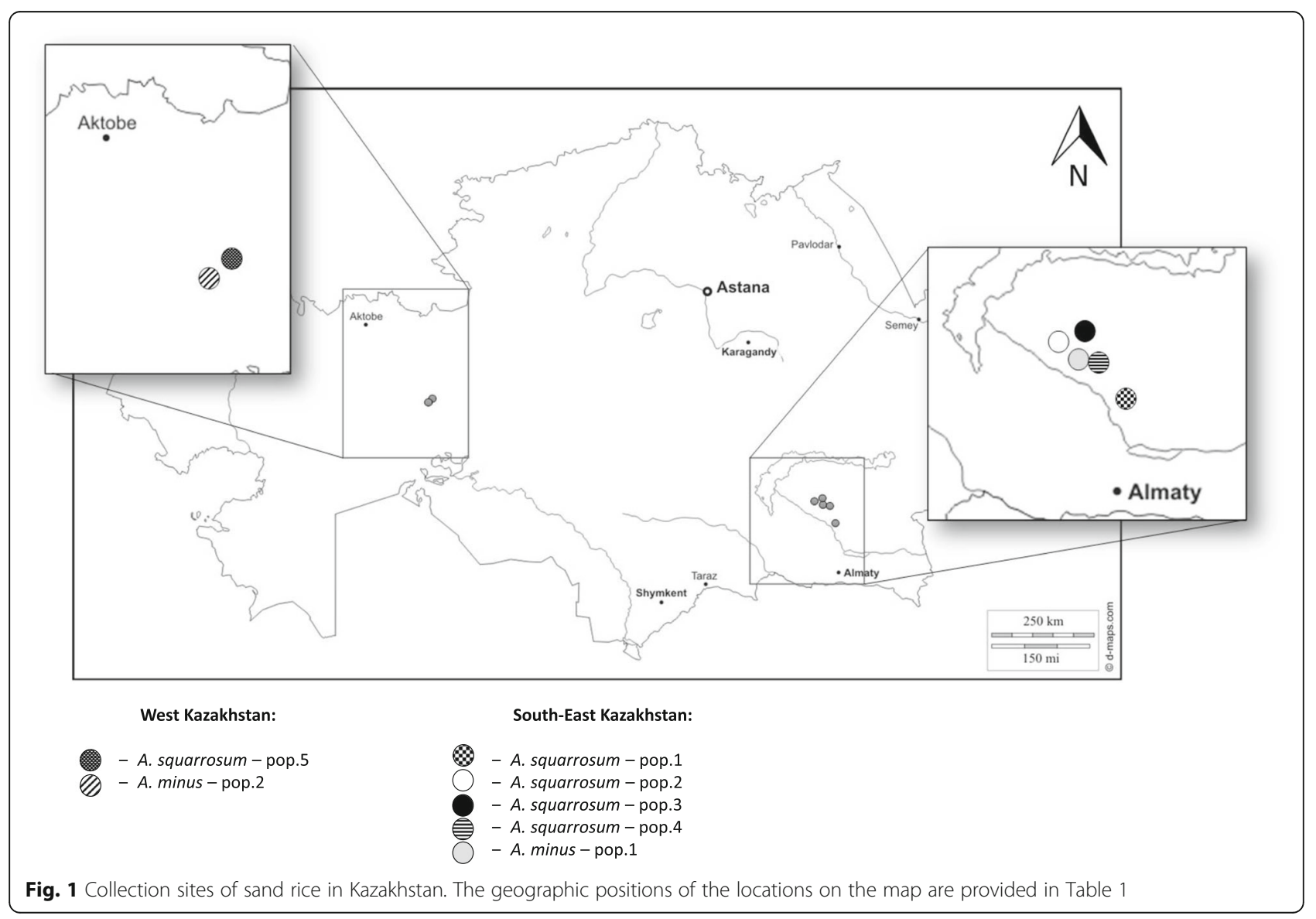


Table 2 Primer sequences for the rDNA ITS region and the chloroplast matK gene

\begin{tabular}{llll}
\hline Primers & Nucleotide sequence & Annealing temperature $^{\prime}$ & Expected sizes $^{a}$ \\
\hline ITS1nF & 5'-AGAAGTCGTAACAAGGTTCCGTAGG- 3' & $58^{\circ} \mathrm{C}$ & $600-680$ bp \\
ITS4nR & 5'-TCCTCCGCTATTGATATGC- 3' & & \\
matK-F & 5'-CCTATCCATCTGGAAATCTTAG- 3' & $50^{\circ} \mathrm{C}$ & $750-800$ bp \\
matK-R & 5'-GTTCTAGCACAAGAAAGTCG- 3' & & \\
\hline
\end{tabular}

a expected sizes are approximate lengths of amplicons usually obtained from Caryophyllales according to data in GenBank [34]

dry leaf material according to the modified Dellaporta DNA extraction protocol [24]. PCR fragments were amplified for the maturase $\mathrm{K}$ gene of the chloroplast genome (matK) [25] and the nuclear ribosomal ITS region [26].

All PCR reactions were carried out in $16 \mu \mathrm{l}$ volumes in a Veriti Thermo cycler (Applied Biosystems, Foster City, CA, USA). One PCR reaction contains $4 \mathrm{mM}$ of each $\mathrm{dNTP}, 6.4 \mathrm{mM}$ of primer mix, $1.6 \mathrm{U}$ of Taq DNA polymerase and $80 \mathrm{ng}$ of total genomic DNA. Protocols for PCR reactions were taken from Jun et al. [27]. Primers chosen for PCR, their nucleotides sequence and sizes are given in Table 2.

PCR products were run in $1.5 \%$ agarose gels. Single bands with expected sizes around $750 \mathrm{bp}$ for matK and $650 \mathrm{bp}$ for ITS were cut out from gels and purified using ULTRAPrep ${ }^{\circledR}$ Agarose Gel Extraction Mini Prep Kit (AHN Biotechnologie GmbH, Nordhausen, Germany) according to the protocol provided by the company.

Purified DNA amplicons were used for the sequence reactions with forward and reverse primers separately. All reactions were performed with the BigDye Terminator Cycle Sequencing technology (Applied Biosystems, Foster City, CA, USA). Each reaction was carried out in $20 \mu \mathrm{l}$ volume according to the protocol of the company.

\section{Alignment and phylogenetic analyses}

DNA sequences were imported to MEGA 6.06 [28] for an alignment together with sequences from the GenBank database with the addition of the outgroup species Chenopodium opulifolium Schrad. ex Koch \& Ziz. and Chenopodium quinoa Willd. Maximum Likelihood analyses [29] with 1000 bootstrap replications and the
Tamura-Nei model [30] of sequence evolution were used to construct a phylogenetic tree.

\section{Results}

In the laboratory, each individual plant was initially identified at the species level by taxonomists using descriptions given in The Flora of Kazakhstan [3]. The species identification was based on differences in the structure of seeds, leaves and spikes (Table 3).

Plant measurements showed a clear difference of $A$. squarrosum from $A$. minus using several traits, such as leaf length, weight and number of seeds $(p<0.001)$. The results from a $t$-test indicated that $A$. squarrosum (in comparison to $A$. minus) had higher seed weights $(P<0.01)$, more seeds per spike $(P<0.05)$, and longer leaves $(P<0.05)$.

\section{Variability at ITS region and matK gene}

From each population listed in Table 1 three individual plants were selected for DNA extraction. In total, 21 DNA samples were sequenced for ITS and matK. ITS sequences had a size range from 629 to $662 \mathrm{bp}$. The sequences were aligned in MEGA 6.06 and compared to GenBank references. Since sequences showed no variability in both ITS and mat $\mathrm{K}$ among the individuals of single populations, one sample per population was been chosen for further work. As a result, 24 nucleotide substitutions in the ITS region were detected that distinguish $A$. minus from $A$. squarrosum (Fig. 2). The total variability of ITS sequences in this study was $3.6 \%$.

We found no variation in ITS sequences among samples from two populations of $A$. minus collected in different parts of Kazakhstan and NCBI GenBank specimens.

Table 3 Morphometric analysis of key sand rice traits. All data are represented as a mean value for all plants in each population with SEM

\begin{tabular}{lllllll}
\hline Region & Species, population № & Leaf length, $\mathrm{cm}$ & Seed diameter, $\mathrm{cm}$ & Spike length, $\mathrm{cm}$ & 50 seeds weight, mg & $\begin{array}{c}\text { Number of seeds } \\
\text { per spike }\end{array}$ \\
\hline Southeastern KZ & A.squarrosum pop.1 & $4.36 \pm 0.06$ & $0.52 \pm 0.021$ & $1 \pm 0.033$ & $40.8 \pm 0.573$ & $16 \pm 0.422$ \\
& A.squarrosum pop.2 & $3.2 \pm 0.041$ & $0.61 \pm 0.041$ & $1.6 \pm 0.071$ & $60 \pm 1.78$ & $20 \pm 0.817$ \\
& A.squarrosum pop.3 & $8.18 \pm 0.105$ & $0.51 \pm 0.021$ & $2 \pm 0.045$ & $57 \pm 0.667$ & $26 \pm 0.422$ \\
& A.squarrosum pop.4 & $2.7 \pm 0.039$ & $0.5 \pm 0.021$ & $1 \pm 0.021$ & $53 \pm 0.869$ & $18 \pm 0.422$ \\
& A.minus pop.1 & $1.9 \pm 0.077$ & $0.51 \pm 0.032$ & $1.2 \pm 0.055$ & $33 \pm 1$ & $14 \pm 0.512$ \\
Western KZ & A.squarrosum pop.5 & $4 \pm 0.052$ & $0.58 \pm 0.02$ & $1.4 \pm 0.037$ & $50 \pm 0.803$ & $18 \pm 0.422$ \\
& A.minus pop.2 & $1.79 \pm 0.062$ & $0.5 \pm 0.03$ & $1.7 \pm 0.079$ & $32 \pm 0.912$ & $12 \pm 0.417$ \\
\hline
\end{tabular}




\begin{tabular}{|c|c|c|c|c|c|c|c|c|c|c|c|c|c|c|c|c|c|c|c|c|c|c|c|c|}
\hline $\begin{array}{l}\text { No. } \\
\text { Nucleotide position }\end{array}$ & $\begin{array}{c}1 \\
22 \\
\end{array}$ & $\begin{array}{c}2 \\
24 \\
\end{array}$ & $\begin{array}{c}3 \\
29 \\
\end{array}$ & $\begin{array}{c}4 \\
54 \\
\end{array}$ & $\begin{array}{c}5 \\
73 \\
\end{array}$ & $\begin{array}{c}6 \\
79 \\
\end{array}$ & $\begin{array}{c}7 \\
84 \\
\end{array}$ & $\begin{array}{c}8 \\
89 \\
\end{array}$ & $\begin{array}{c}9 \\
95 \\
\end{array}$ & $\begin{array}{c}10 \\
121 \\
\end{array}$ & $\begin{array}{c}11 \\
129 \\
\end{array}$ & $\begin{array}{c}12 \\
158 \\
\end{array}$ & $\begin{array}{c}13 \\
161 \\
\end{array}$ & $\begin{array}{c}14 \\
166 \\
\end{array}$ & $\begin{array}{c}15 \\
185 \\
\end{array}$ & $\begin{array}{c}16 \\
204 \\
\end{array}$ & $\begin{array}{c}17 \\
373 \\
\end{array}$ & $\begin{array}{c}18 \\
394 \\
\end{array}$ & $\begin{array}{r}19 \\
477 \\
\end{array}$ & $\begin{array}{r}20 \\
527 \\
\end{array}$ & $\begin{array}{c}21 \\
568 \\
\end{array}$ & $\begin{array}{c}22 \\
578 \\
\end{array}$ & $\begin{array}{r}23 \\
581 \\
\end{array}$ & $\begin{array}{c}24 \\
582 \\
\end{array}$ \\
\hline JF792730.1 A.squarrosum * & A & $\mathrm{T}$ & A & G & G & $\mathrm{C}$ & G & A & $\mathrm{T}$ & A & $\mathrm{T}$ & A & - & C & C & G & $A$ & $A$ & G & $\mathrm{T}$ & $\mathrm{T}$ & $\mathrm{T}$ & $\mathrm{T}$ & G \\
\hline A.squarrosum pop.1 & . & . & . & . & . & . & $\mathrm{C}$ & . & . & . & . & . & - & . & . & . & . & $\mathrm{T}$ & . & . & . & . & . & . \\
\hline A.squarrosum pop. 2 & . & . & . & . & . & . & $\mathrm{C}$ & . & . & . & . & . & - & . & . & . & . & $\mathrm{T}$ & . & . & . & . & . & \\
\hline A.squarrosum pop. 3 & . & . & . & . & $\cdot$ & . & $\mathrm{C}$ & . & . & . & . & . & - & . & . & . & . & $\mathrm{T}$ & . & . & . & . & . & \\
\hline A.squarrosum pop. 4 & . & . & . & . & $\cdot$ & . & $\mathrm{C}$ & . & . & . & . & . & - & . & . & . & . & $\mathrm{T}$ & . & . & . & . & . & $\cdot$ \\
\hline A.squarrosum pop. 5 & . & . & . & . & $\cdot$ & . & A & . & . & . & . & . & - & . & . & . & . & . & . & . & . & . & . & . \\
\hline KT229652.1 A.minus * & G & G & $\mathrm{T}$ & C & A & $\mathrm{T}$ & $C$ & G & C & G & C & G & C & $\mathrm{T}$ & $\mathrm{T}$ & $A$ & G & . & $A$ & C & C & C & $A$ & A \\
\hline A.minus pop.1 & G & G & $\mathrm{T}$ & C & A & $\mathrm{T}$ & C & G & C & G & $\mathrm{C}$ & G & C & $\mathrm{T}$ & $\mathrm{T}$ & $A$ & G & . & $A$ & C & C & C & $A$ & A \\
\hline A.minus pop. 2 & G & G & $\mathrm{T}$ & $\mathrm{C}$ & $A$ & $\mathrm{~T}$ & $\mathrm{C}$ & $\mathrm{G}$ & $C$ & $\mathrm{G}$ & C & G & $C$ & $\mathrm{~T}$ & $\mathrm{~T}$ & $A$ & G & & $A$ & $C$ & C & C & $A$ & A \\
\hline
\end{tabular}

Fig. 2 Polymorphic sites of A. squarrosum and A. minus detected in ITS. A. squarrosum pop. 1, 2, 3, 4 and A. minus pop. 1 were collected in Southwest Kazakhstan; A. squarrosum pop. 5 and A. minus pop. 2 - West Kazakhstan. * - indicates GenBank sequences, with reference numbers, from the NCBI database

Sequences of ITS from A. squarrosum, on the contrary, showed two polymorphic nucleotides (pos. 84 and 394) distinguishing populations from southeastern and western parts of Kazakhstan (Fig. 2). The same two nucleotides separated our $A$. squarrosum samples from sequences deposited in NCBI GenBank and samples from southeastern populations of $A$. squarrosum, but only one nucleotide in position 394 was different between the GenBank accession (from China) and samples from the West Kazakhstan population (Fig. 2).

Sequences of mat $\mathrm{K}$ for samples of $A$. squarrosum in both regions were all identical. Fourteen polymorphic sites between $A$. squarrosum and $A$. minus were identified in this study. The nucleotide in position 503 separated $A$. squarrosum growing in Kazakhstan from the sequence available in GenBank (Fig. 3). The total length of the matK alignment in this study was 768 nucleotides. The variability of sequences was $1.8 \%$.

\section{Differentiation of two Agriophyllum species based on ITS region and matK gene sequencing}

In order to reveal genetic differentiation between two species, ITS sequences were used for the construction of a phylogenetic tree (Fig. 4) together with two outgroup taxa.

The ITS-derived phylogenetic tree showed a clear separation of Agriophyllum species into two clades, i.e. $A$. squarrosum and $A$. minus. Two populations of $A$. minus and NCBI GenBank sequence had identical ITS sequences. In contrast, the population of A. squarrosum from western Kazakhstan and the GenBank sequence from China formed a clade separate from the populations collected in the southeastern region of Kazakhstan.

In the matK tree (Fig. 5) the Agriophyllum species were grouped into two sister clades. Despite the large geographic distances between the studied populations of $A$. squarrosum and $A$. minus, the samples within both species displayed no infra-specific variation.

\section{Discussion}

Sand rice is a common plant of extreme desert conditions of Asia with its well-adapted morphology and physiology. Economic importance, nutritional and fodder value, stress tolerance, and its use for fixation of shifting sands are underlining the importance of this species for humankind [6]. In the last decade, several studies have increased our knowledge on sand rice, discussing its

\begin{tabular}{lcccccccccccccc} 
No. & 1 & 2 & 3 & 4 & 5 & 6 & 7 & 8 & 9 & 10 & 11 & 12 & 13 & 14 \\
Nucleotide position & 5 & 53 & 141 & 157 & 227 & 264 & 311 & 390 & 475 & 503 & 624 & 646 & 664 & 752 \\
\hline AY514827.1 A.squarrosum* & $\mathrm{A}$ & $\mathrm{G}$ & $\mathrm{G}$ & $\mathrm{T}$ & $\mathrm{A}$ & $\mathrm{G}$ & $\mathrm{T}$ & $\mathrm{C}$ & $\mathrm{G}$ & $\mathrm{C}$ & $\mathrm{T}$ & $\mathrm{C}$ & $\mathrm{G}$ & $\mathrm{G}$ \\
A.squarrosum pop.1 &. &. &. &. &. &. &. &. &. & $\mathrm{G}$ &. &. &. &. \\
A.squarrosum pop.2 &. &. &. &. &. &. &. &. &. & $\mathrm{G}$ &. &. &. &. \\
A.squarrosum pop.3 &. &. &. &. &. &. &. &. &. & $\mathrm{G}$ &. &. &. &. \\
A.squarrosum pop.4 &. &. &. &. &. &. &. &. &. & $\mathrm{G}$ &. &. &. &. \\
A.squarrosum pop.5 &. &. &. &. &. &. &. &. &. & $\mathrm{G}$ &. &. &. &. \\
A.minus pop.1 & $\mathrm{C}$ & $\mathrm{A}$ & $\mathrm{T}$ & $\mathrm{G}$ & $\mathrm{C}$ & $\mathrm{T}$ & $\mathrm{C}$ & $\mathrm{T}$ & $\mathrm{A}$ & $\mathrm{G}$ & $\mathrm{G}$ & $\mathrm{T}$ & $\mathrm{A}$ & $\mathrm{A}$ \\
A.minus pop.2 & $\mathrm{C}$ & $\mathrm{A}$ & $\mathrm{T}$ & $\mathrm{G}$ & $\mathrm{C}$ & $\mathrm{T}$ & $\mathrm{C}$ & $\mathrm{T}$ & $\mathrm{A}$ & $\mathrm{G}$ & $\mathrm{G}$ & $\mathrm{T}$ & $\mathrm{A}$ & $\mathrm{A}$
\end{tabular}

Fig. 3 Polymorphic sites of A. squarrosum and A. minus detected in the matk gene. A. squarrosum pop. 1, 2, 3, 4 and A. minus pop. 1 were collected in southeastern Kazakhstan; A. squarrosum pop. 5 and A. minus pop. 2 in western Kazakhstan. ${ }^{*}-$ indicates GenBank sequences, with their reference numbers 


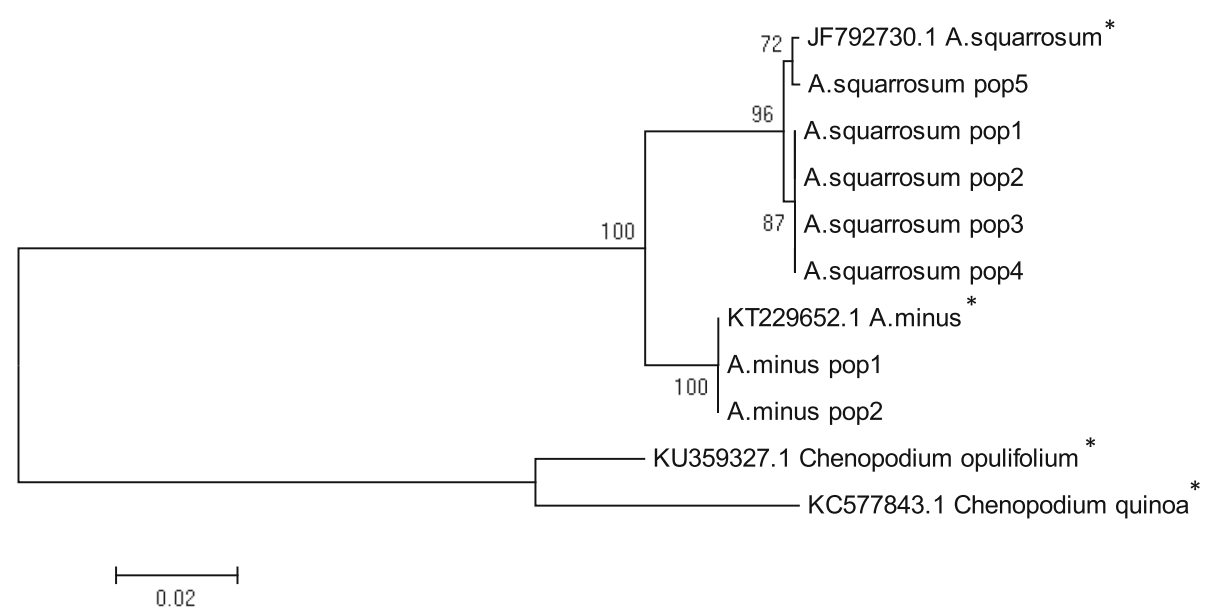

Fig. 4 Maximum Likelihood phylogenetic tree resulted from analysis of the ITS sequences. The length of branches is based on Maximum Composite Likelihood analysis and numbers at nodes shows a probability bootstrap. ${ }^{*}$ - indicates GenBank sequences, with reference numbers, from the NCBI database

potential economical relevance [9]. However, the literature survey is suggesting that so far there were no attempts to study the genetic diversity of the genus Agriophyllum using molecular tools. Beside this, it is important to obtain basic facts related to the diversity of morphological traits of plants growing in different parts of the Agriophyllum distribution area.

In this study two different species, A. squarrosum and A. minus, were collected in two different regions of the Central Asia, separated by more than $1250 \mathrm{~km}$ distance. Samples from seven different populations were collected and studied using basic morphological characters and two DNA markers, ITS and matK.

Domestication of Agriophyllum species as a food crop or pasture and fodder crops requires particular morphological traits. Both species studied here are the most common representatives of genus Agriophyllum in
Kazakhstan. The results of our work suggested differences in morphological traits of $A$. squarrosum and $A$. minus in both regions. Morphometric analysis of key characters, such as leaf length, seed weight, and number of seeds per spike, clearly showed a difference between A. squarrosum and A. minus (Table 3 ).

The alignment of ITS and mat $\mathrm{K}$ sequences in the study showed that variation in ITS (3.6\% of variability) was two times higher than in matK ( $1.8 \%$ of variability), suggesting that ITS analysis is providing better resolution in comparison with the analysis using matK as a chloroplast marker. The difference in sequence variability can be explained by lower mutation rate of the plastid genome [31] and by the mainly non-coding nature of the internal transcribed spacers region of rDNA. The ITS region can accumulate large amounts of mutations but with only small certain constraints

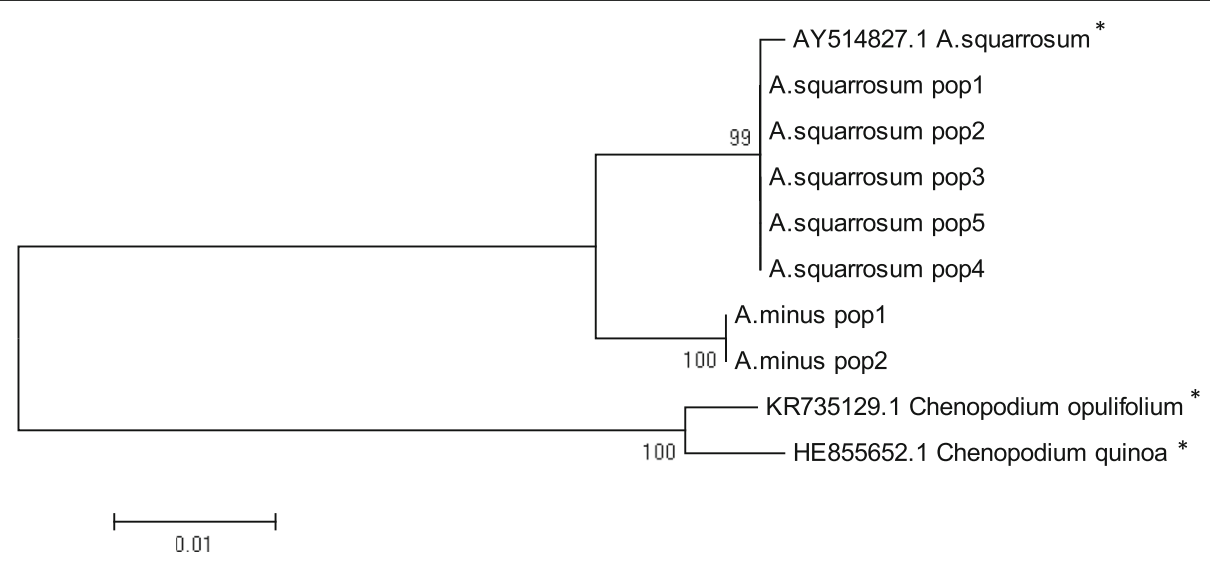

Fig. 5 Maximum Likelihood phylogenetic tree resulted from analysis of the matk sequences. The length of branches is based on Maximum Composite Likelihood analysis and numbers at nodes shows a probability bootstrap. * - indicates GenBank sequences, with reference numbers, from the NCBI database 
due to its functional role, and, therefore, this marker is commonly used in phylogenetic analysis and DNA barcoding [32, 33].

Despite this difference in sequence variability, the topology of phylogenetic trees using both markers showed congruency in separation of A. squarrosum from A. minus. DNA analysis of all plants in populations revealed no hybrid specimens among collected samples of $A$. squarrosum and A. minus, and suggested that for these two sympatric species no gene flow occurs, at least not for the analyzed populations.

\section{Conclusions}

Our study is the first attempt to analyze the taxonomic relationship and genetic differences of $A$. squarrosum and $A$. minus, which are annual plant species adapted to the mobile sand dunes in desert and semi-desert regions of Central Asia and China. Representatives of seven populations of $A$. squarrosum and $A$. minus were analyzed using two universally recognized plant DNA barcode markers, ITS and matK. The results obtained suggested that variability of ITS is twice as high as in matK sequences. However, the phylogenetic trees from both markers are congruent, showing clear separation of the two species. The ITS tree separated the samples from the two areas of Kazakhstan, suggesting a possibility of incorporation of this marker in a broad analysis of population genetics study of $A$. squarrosum. The results of morphological analysis confirmed differences between $A$. squarrosum and $A$. minus for key agronomic traits, such as leaf length, seed weight, and number of seeds per spike.

\section{Acknowledgements}

The authors would like to acknowledge the funding from the Ministry of Education and Sciences of the Republic of Kazakhstan for national program N0237.

\section{Funding}

Publication of this article has been funded by national program N0237 given by the Ministry of Education and Sciences of the Republic of Kazakhstan. The funder did not participate in study design, data collection and analysis, decision to publish, or preparation of the manuscript.

\section{Availability of data and materials}

The datasets supporting the conclusions of this article are included within the article. The voucher specimens are deposited in the herbarium of the Institute of Plant Biology and Biotechnology (Kazakhstan).

\section{About this supplement}

This article has been published as part of BMC Plant Biology Volume 17 Supplement 1, 2017: Selected articles from PlantGen 2017. The full contents of the supplement are available online at https:// bmcplantbiol.biomedcentral.com/articles/supplements/volume-17supplement-1.

\section{Authors' contributions}

SA and YT carried out the experimental design. AZ and YT collected Agriophyllum species in West and South-east regions, respectively. AZ and YT performed morphological descriptions and developed herbarium specimens. YG carried out the DNA extraction, DNA sequencing and the alignment of sequences. SA, YT and YG participated in preparation of the manuscript. All authors reviewed the draft of the manuscript. All authors read and approved the final manuscript.

Ethics approval and consent to participate

This study does not contain any research requiring ethical consent or approval.

\section{Consent for publication}

Not applicable.

\section{Competing interests}

The authors declare they have no competing interests.

\section{Publisher's Note}

Springer Nature remains neutral with regard to jurisdictional claims in published maps and institutional affiliations.

\section{Author details}

${ }^{1}$ Institute of Plant Biology and Biotechnology, Almaty, Kazakhstan050040.

${ }^{2}$ Aktobe breeding station, Aktobe region, Kazakhstan030014.

Published: 14 November 2017

\section{References}

1. Kühn U, Bittrich V, Carolin R, Freitag H, Hedge IC, Uotila P, Wilson PG. Chenopodiaceae. In: Kubitzki K, Rohwer JG, Bittrich, editors. The families and genera of vascular plants, vol. 2. Berlin: Springer; 1993. p. 253-81.

2. Kadereit $\mathrm{G}$, Borsch $\mathrm{T}$, Weising $\mathrm{K}$, Freitag $\mathrm{H}$. Phylogeny of Amaranthaceae and Chenopodiaceae and the evolution of $\mathrm{C}_{4}$ photosynthesis. Int J Plant Sci. 2033:164:959-86.

3. Ageeva NT, Baitenov MB, Goloskokov VP, Kornilova VS, Pavlov NV, Poljakov PP. Agriophyllum M.B. In: Pavlov NV editor. Flora of Kazakhstan. Alma-ata: Academy of science of KazSSR. 1960;3:241-3.

4. Bayev AA, Vienberg GG, Zavarzin GA. Biological encyclopedic dictionary. 2nd ed. Moscow: Sov. Encyclopedia; 1986.

5. Bakshi K. Not only porridge. Ogoniok J. 1962:23:9-11.

6. Chen G, Zhao J, Zhao X, Zhao P, Duan R, Nevo E, Ma X. A psammophyte Agriophyllum squarrosum (L.) Moq.: a potential food crop. Genet Resour Crop Evol. 2014;61:669.

7. Ivanov W. Plant field guide on north near-Caspian region: Chenopodiaceae, Liliaceae. Leningrad: Nauka; 1989.

8. Gong B, Zhan KX, Zhou YH, Zhang L, Hui YQ, LI YS. Separation and identification of chemical constituents from Agriophyllum squarrosum (L.) Moq. Chin Med Mat. 2012;10:7-11.

9. Nemoto M, Lu X. Ecological characteristics of Agriophyllum squarrosum, a pioneer annual on sand dunes in eastern Inner Mongolia, China. Ecol Res. 1992:7:183

10. Wang S, Wan C, Wang Y, Chen H, Zhou Z, Fu H, Sosebee RE. The characteristics of $\mathrm{Na}^{+}, \mathrm{K}^{+}$and free proline distribution in several droughtresistant plants of the Alza Desert, China. J Arid Environ. 2014;56:525-39.

11. Miao CP, Li XH, Jiang DM. Spatial variability of Agriophyllum squarrosum across scales and along the slope on an active sand dune in semi-arid China. Arid Land Res Manag. 2012;27:231-44.

12. Hanelt P. Mansfeld's Encyclopedia of Agricultural and Horticultural Crops. Berlin: Springer. 2001; p. 258.

13. Bai W, Bao X, Li L. Effect of Agriophyllum squarrosum seed banks on its colonization in a moving sand dune in Hunshandake sand land of China. J Arid Environ. 2004:59:151-7.

14. Zhao P, Zhang J, Qian C, Zhou Q, Zhao X, Chen G, Ma XF. SNP discovery and genetic variation of candidate genes relevant to heat tolerance and agronomic traits in natural populations of sand rice (Agriophyllum squarrosum). Front Plant Sci. 2017:8:536.

15. Chen G, Zhao J, Zhao X, Zhao P, Zhang J. A potential food crop Agriophyllum squarrosum. In: Plant Genetics, Genomics, Bioinformatics and Biotechnology (PlantGen2017): proceedings. Almaty: IPBB; 2017. p. 14.

16. Kress WJ. Plant DNA barcodes: applications today and in the future. JSE. 2017: https://doi.org/10.1111/jse.12254.

17. Hebert PD, Cywinska A, Ball SL, de Waard JR. Biological identifications through DNA barcodes. Proc Biol Sci. 2003; https://doi.org/10.1098/rspb. 2002.2218. 
18. Hebert PDN, Gregory TR. The promise of DNA barcoding for taxonomy. Syst Biol. 2005;54(5):852-9.

19. Kress WJ, Erickson DL. A two-locus global DNA barcode for land plants: the coding rbcL gene complements the non-coding trnH-psbA spacer region. PLoS One. 2007;2(6):e508.

20. Li X, Yang Y, Henry RJ, Rossetto M, Wang Y, Chen S. Plant DNA barcoding: from gene to genome. Biol Rev Camb Philos Soc. 2015;90(1):157-66.

21. Alvarez I, Wendel JF. Ribosomal ITS sequences and plant phylogenetic inference. Mol Phylogenet Evol. 2003;29(3):417-34.

22. Turuspekov Y, Abugalieva S. Plant DNA barcoding project in Kazakhstan. Genome. 2015:58:290.

23. Chaoju Q, Hengxia Y, Yong S, Jiecai Z, Chengliang Y et al. Population dynamics of Agriophyllum squarrosum, a pioneer annual plant endemic to mobile sand dunes, in response to global climate change. Scientific Reports 6. 2016; doi:https://doi.org/10.1038/srep26613.

24. Dellaporta SL, Wood J, Hicks JB. A plant DNA mini preparation: version II. Plant Mol Biol Rep. 1983;1:19-21.

25. Hollingsworth PM, Graham SW, Little DP. Choosing and using a plant DNA barcode. PLoS ONE. doi.org/10.1371/journal.pone.0019254.

26. White TJ, Bruns T, Lee S, Taylor JW. PCR protocols: a guide to methods and applications. In: Innis MA, Gelfand DH, Sninsky JJ, White TJ, editors. Amplification and direct sequencing of fungal ribosomal RNA genes for phylogenetics. New York: Academic Press, Inc; 1990.

27. Jun W, Nian-He X. Ardisia crenata Complex (Primulaceae) studies using morphological and molecular data. In: Mworia JK editor. Botany. London: InTech; 2012. p. 163-72.

28. Tamura K, Stecher G, Peterson D, Filipski A, Kumar S. MEGA6: molecular evolutionary genetics analysis version 6.0. Mol Biol Evol. 2013;30(12):2725-9.

29. Felsenstein J. Evolutionary trees from DNA sequences: a maximum likelihood approach. J Mol Evol. 1981;17:368-76.

30. Tamura K, Nei M. Estimation of the number of nucleotide substitutions in the control region of mitochondrial DNA in humans and chimpanzees. Mol Biol Evol. 1993;10:512-26.

31. Smith DR. Mutation rates in plastid genomes: they are lower than you might think. Genome Biol Evol. 2015;7(5):1227-34.

32. Schoch CL, Seifert KA, Huhndorf S, Robert V, Spouge JL, Levesque CA, Chen W. And fungal Barcoding consortium. Nuclear ribosomal internal transcribed spacer (ITS) region as a universal DNA barcode marker for Fungi. Proc Natl Acad Sci U S A. 2012:109(16):6241-6.

33. Tripathi AM, Tyagi A, Kumar A, Singh A, Singh S, Chaudhary LB, Roy S. The internal transcribed spacer (ITS) region and trnhH-psbA are suitable candidate loci for DNA barcoding of tropical tree species of India. PLoS One. 2013;8(2):e57934.

34. National Center for Biotechnology Information. U.S. National Library of Medicine, Rockville Pike, 1988. https:/www.ncbi.nlm.nih.gov. Accessed 29 Jun 2017

\section{Submit your next manuscript to BioMed Central and we will help you at every step:}

- We accept pre-submission inquiries

- Our selector tool helps you to find the most relevant journal

- We provide round the clock customer support

- Convenient online submission

- Thorough peer review

- Inclusion in PubMed and all major indexing services

- Maximum visibility for your research

Submit your manuscript at www.biomedcentral.com/submit

) Biomed Central 